\title{
MARKET NAMES IN MEDAN: A NATURAL SEMANTIC METALANGUAGE STUDY
}

\author{
Latifah Yusri Nasution, Mulyadi \\ Faculty of Cultural Studies, Universitas Sumatera Utara, Indonesia \\ Jalan Abdul Hakim No. 1 P. Bulan Medan, North Sumatera, Indonesia \\ Corresponding Author: latifahyusri22@gmail.com
}

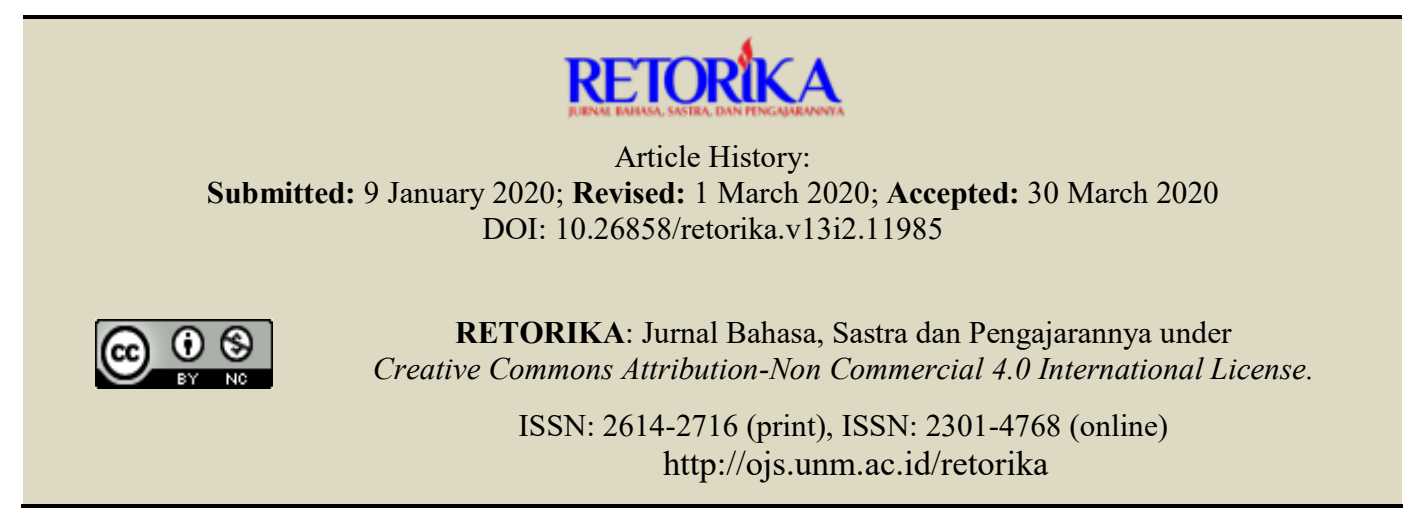

\begin{abstract}
This article aims to investigate market names in Medan. This study used natural semantic metalanguage theory. The type of this research is descriptive qualitative. In data collection, interviews and observations were conducted. The results showed that Medan people named their markets based on the markets' location, time and environmental conditions. Market names in Medan contain denotative or connotative meaning. The difference in the market name's meaning reflects thoughts underlying the word. The paraphrase of the market name's meaning can provide an understanding of the use of market names in Medan.
\end{abstract}

Keywords: natural semantic metalanguage, semantic primitives, market name

Names are words that become labels for every creature, object, activity, and event in this world and names appear in complex and varied human lives (Darheni, 2010:57 compared to Munazar, 2016: 28, Palmer, 1981: 129). In this case, names serve as a marker to distinguish one another.

The naming of an object or proper name is a noun that refers to one particular entity (Bach: 2002). Crystal (in Darheni: 2010) states that the study of proper names is called nomastic or onomatology. According to him, the study has branches, namely Anthroponomastic which focuses on the study of the person names and Toponomastics focusing on the study of place names. This study focuses on the name of the places which are markets in Medan using natural semantic metalanguage study. By examining the names of the market in Medan, it will reveal the mindset of Medan people. In addition, this study is useful for preserving Medan's toponym amidst the inevitable flow of globalization and modernization.

Natural semantic metalanguage was pioneered by Anna Wierzbicka and her colleagues, Cliff Goddard, Felix Ameka, Hilary Chappell, and Jean Harkins. The basic assumption in NSM theory is related to the semiotic principle which 
states that the analysis of meaning will be discrete and complete which means any complex meaning can be explained without whirling and residue in combination of other discrete meanings (Goddard in Mulyadi, 2006:69).

The following is an example of NSM study in the nickname of the American president (Gladkova: 2002): The Father of Our Country (George Washington):(a) people think about $\mathrm{X}$ like this, (b) a long time ago $\mathrm{X}$ did many good things for this country, (c) no one else did things like this before, (d) no one else could do things like this after, (e) because $\mathrm{X}$ did these things, this country can exist, (f) it is good if we think about what this person did.

In Gladkova's research on the nickname of American president examined using the NSM study, it can be seen the differences in meaning expressed by the citizens about the figure of president leading the United States.

In addition to research conducted by Gladkova, Fatikhudin (2018) in his research discussed the semantics of place names in terms of cognitive semantics. Khotimah and Ika (2019) in the Semantic Study of the Madurese student name in the Indonesian Language and Literature Education Study Program at Trunojoyo Univer-sity, Madura found that the name selection is always done by considering one or several things, namely the meaning of the name itself.

According to Darheni (2010), there are two experiences that humans consider in naming a place, namely: (1) considerations produced by the processes, characteristics, or qualities shown by nature and the names of the human manipulation result, and (2) Considerations based on ideas, hopes, dreams, and the human interest in the place in accordance with what he wants.

Based on the study above, it is necessary to examine the original meaning of the market names in Medan. The names of the market in Medan are unique because they are referred to as $p a-$ jak 'tax', for example, pamela (Pajak Melati), Pajus (Pajak USU), Pajak ikan 'Fish tax' and Pajak Sore 'Afternoon tax'. The purpose of this study is to investigate the market names in Medan using the theory of natural semantic metalanguage.

\section{METHOD}

In this qualitative study, data were collected in the form of words, using a descriptive method and of language in a natural special context by utilizing various natural methods (Moleong, 2006:5). Sutopo (2002: 111) states that qualitative descriptive research leads to a detailed and in-depth description about the portrait of what ctually happens according to what is in the field of study.

Data sources of this research were words, phrases, or sentences obtained from the utterances of Medan people and online searches on the website. The study was conducted by collecting verbal and non-verbal data. Data collected in the form of words, phrases, and sentences contained market names in Medan. For data collection techniques, this study used listening and speaking methods (Sudaryanto: 2015).

Furthermore, for data analysis, the analytical method according to Miles and Huber-man (1992) was used in three stages, namely: (1) data condensation, (2) data display, and (3) drawing conclusions in accordance with the step procedure of each stage.

At the condensation stage, the following steps were carried out: (1) reading the data collected as a whole and (2) determining the distribution of market names in Medan. There are three divisions of market naming in Medan, namely naming based on location, time, and market environmental condition. Data of market names in Medan have been collected in Table 1 .

\section{Table 1. Names of Market in Medan}

\begin{tabular}{lll}
\hline Location & Time & Market Environment \\
& & \\
\hline Pajak USU & Pajak Sore & Pajak Ikan lama \\
Pajak Petisah & Pajak Pagi & Pajak Ular \\
Pajak Melati & & Pajak Bengkok \\
Pajak Pringgan & Pajak Beruang \\
Pajak Sambas & Pajak Hongkong \\
Pajak Sukaramai & Pajak Sambu \\
Pajak Hindu & \\
\hline
\end{tabular}

At the data display stage, the following steps were taken: (1) data classification, (2) analysis of the semantic structure of the market names in Medan, and (3) the elaboration of the components obtained to produce a meaning confi-guration regarding special features, especially applying paraphrases of the market names in Medan using natural semantic matalanguage theory.

To analyze and identify the data, natural semantic metalanguage theory (NSM) was used. NSM theory could explain the meaning of the 
market names in Medan clearly without whirling. The research procedures using NSM theory were: (1) determining the original meaning of the words analyzed, (2) searching for the exact polysemy of their meaning, (3) revealing other semantic properties in the meaning of the words accompanied by syntax and semantics evidence, (4) comparing the semantic properties of words that are related to show their similarities and differences in meaning, and (5) forming SMU based on the found semantic properties, and (6) paraphrasing or applying meaning to the words (Mulyadi and Rumnasari, 2006:72).

There were two steps taken at the conclusion stage, namely (1) checking and repeating the steps of data analysis and (2) drawing conclusions about how to name markets in Medan and paraphrase market names in Medan using natural semantic metalanguage theory.

\section{FINDINGS AND DISCUSSION}

\section{Findings}

There were three ways of naming markets in Medan, namely naming markets based on location, naming markets based on time, and naming markets based on environmental conditions. The following is the elaboration of each market name in Medan.

\section{The Name of Market Based on Location}

\section{Pajak USU 'USU Market'}

Pajak USU is located in Jamin Ginting Street and near Universitas Sumatera Utara (USU) campus. The market is well known for its friendly cost for students in Medan. Students' needs, such as learning tools, electronical devices, practical assignment tools and souvenirs are available here.

The market is named after Pajak USU because it is located around the USU campus area and all visitors are commonly students from USU. The following sentences are the paraphrases meaning of USU market based on the location:

\section{Pajak USU (X)}

a. Many things in $X$

b. X near a big place

c. People think, want to know a lot of things in this big place d. Everyone in this big place knows $\mathrm{X}$

e. If someone says $X$, other people will think of something

f. Something good is in X

g. At $\mathrm{X}$ someone wants to see and feel something.

Based on the paraphrase above, it can be seen that Pajak USU is a place to get something (a). The location of the pajak USU market is close to a big place and at that place people think and want to know a lot of things so this place is a place to study $(b, c)$, Universitas Sumatera Utara (USU). Pajak USU are popular among students who are studying in USU (d). At Pajak USU, various types of student needs are sold (e) and items sold are very useful to help the students study (f). In addition to buying staff, Pajak USU visitors sometimes just want to take a look at goods. In other words, it is called spend the time check the other out.

\section{Pajak Petisah}

Pajak Petisah is one of the well-known traditional markets in Medan. This market is located in Kota Baru street 3, central Petisah, Medan Petisah district, Medan. The market which is contemporary with Medan is always crowded with buyers, including travelers who come from outside Medan. The travelers usually buy souvenirs to take home.

Pajak Petisah is the name given to this market because this market is located in the district of Medan Petisah. Petisah District is located in the center of Medan. So, giving the name of the market in accordance with the name of the district make people in Medan interested in shopping in that market which is close to large buildings. One of which is the Mayor office. Based on this explanation, the following sen-tences are the paraphrases meaning of Pajak Petisah based on the location.
Pajak Petisah (Y)
a. $\mathrm{Y}$ is very big
b. Some big places are near $Y$
c. Many people work on something in a big place
d. Everyone knows Y
e. There are many parts in $Y$
f. If someone says $Y$, people will think of something
g. Something good in the Y 


\section{h. At Y someone wants to do something}

According to the paraphrase above, it can be seen that the Petisah market is a big place (a) and there are some big buildings near the market (b). It shows that the market is located in a crowded place which is the center of Medan. It is because many people are working in the big buildings around the market (c). From the paraphrase (d) it is conluded that the Petisah market is a place known to Medan people. The market consists of several floors and if we only visit the market once or twice, we may go around several times because of the difficulty to remember the hallways (e). At this market, many things are sold. Because the market is located in the center of the city, it sells all types of needs ( $\mathrm{f}, \mathrm{g}$ ). The Visitors of the market usually come to buy things. A few only comes for spend the time check the other out (h).

\section{Pajak Melati}

The Pajak Melati, commonly abbreviated as Pamela, is found at Simpang Melati Tanjung Anom Medan. Located on Flamboyan street, Medan Tuntungan district, Medan, close to the intersection which is regarded as a strategic location, the market is appealing to the nearby people to visit.

Pajak Melati is the name given to this market because it is located at the intersection of Melati. This naming is to help people if they want to shop at Melati market. By saying Pajak Melati, the drivers of public transportation will directly know that. With the naming, Medan people also like to abbreviate it as Pamela (Pajak Melati or Melati Market). The following sentences are the paraphrases meaning of Pajak Melati based on the location:

Pajak Melati (Z)

a. Z looks small

b. Some people think of the same thing as $\mathrm{Z}$ before they are at the $\mathrm{Z}$

c. Some people know $\mathrm{Z}$

d. Some things are in the $Z$

e. If someone says $Z$, some people will think of something

f. At $\mathrm{Z}$ someone wants to get something.

Based on the paraphrase above, it can be seen that the Pajak Melati is a place that looks small from the outside (a) and when people want to go to the market, they will think that Melati intersection is the location of the market (b). Not everyone knows that market. Some people will ask the location of this market (c). At the market, things such as fruit, vegetables, clothes, and daily needs are sold. Yet, the most well-known goodsat the marketare the second-hand items, often called "Monza". The used items are targeted the most by market visitors (d, e, f).

\section{Pajak Pringgan}

Pajak Pringgan is located in Iskandar Muda street, Pringgan, Babura, Medan Baru district, Medan. The market sells daily housing needs. Conditions at the market area look dirty and seedy. This is due to the large number of street vendors selling in front of the market. In addition, people also throw rubbish away as they like. If occupied with the crowds along with vehicles which stop everywhere, the traffic will be so jammed. The situation is also because of the narrow road nearby.

The market is named Pajak Pringgan because it is located at the Pringgan area. This naming is to help people if they want to shop at the market which is right next to the Ramayana Pringgan. The following sentences are the paraphrases meaning of Pringgan market based on the location.
Pajak Pringgan (A)
a. A looks small
b. A is beside a bigger place
c. Many people are in the bigger place
d. There are some bad things near A
e. If someone says A, some people will think of something
f. Someone wants to get something at A.

Based on the paraphrases above, it can be seen that the Pajak Pringgan is a place that looks small from the outside (a) and adjacent to the Pringgan Ramayana which is often visited by many Medan people $(b, c)$. Some people are lazy to visit the Pajak Pringgan because it is dirty and seedy (d, e). Some people come to the market because they want to buy a number of things related to clothing and food needs (f).

\section{Pajak Sambas}

Pajak sambas is located in Sambas street and near by Tirtanadi Monument, SM Raja street. It is a market that sells a lot of cosmetic tools. In 
addition to that, it also sells various basic necessity products, such as rice, flour, sugar, salt, vegetables, onions, chilies, fish, chicken, and others. The advantages of this traditional market are the products sold are low-priced. So the price is in expensive to people. At the market, sellers and buyers bargain to get a price agreement that is beneficial to both parties.

Pajak Sambas is located on Sambas street. This is a simple naming because the name was taken from the street name. It aims to help people if they want to shop at the market. They only need to come to the Sambas street. The following sentences are the paraphrases meaning of Pajak Sambas based on the location.

Pajak Sambas (B)

a. B looks big

b. Some people think of the same thing as $\mathrm{B}$ before they are at B

c. Some people do not know B

d. If someone says B, some people will think of something good

e. Someone wants to see and get something at B.

By the paraphrases above, it can be seen that the Pajak Sambas is a place that looks big (a). The name of the market is the same as the street name, so people can easily find it (b). Even though easily found, some people do not know this market (c). At the market, various daily needs are sold, but, this market is more famous for selling cosmetics (d). If someone visits the market, he/she usually will compare prices or buy something (e).

\section{Pajak Sukaramai}

Pajak Sukaramai has become one of the central food trade places that is visited by many Medan people. The market is on A.R. Hakim street, Sukaramai II. Until now it is still unsatisfactorily organized both in terms of cleanliness and seller arrangement. This can be seen from the vehicles and people that make the streets crowded. It is because many sellers set up their stand on the highway section. Thus, this makes traffic jam every day.

Pajak Sukaramai is given because it is located in Sukaramai II Village. This is a simple naming because the name of the village taken from the location of the market. It aims to help people if they want to shop at Pajak Sukaramai.
The following sentences are the paraphrases meaning of pajak Sukarame based on the location.
Pajak Sukaramai (C)
a. C big
b. Many people know $\mathrm{C}$
c. There are some bad things near $\mathrm{C}$
d. If someone says $\mathrm{C}$, some people will think of something
e. Someone wants to get something at $\mathrm{C}$.

Based on the paraphrases above, it can be seen that the Pajak Sukaramai is a big place (a) and visited by Medan people (b). Some people are lazy to visit the market because traffic jam often occurs around the road (c). There are sold various kinds of life needs (d). Some people come to the market because they want to buy some things related to their daily needs (e).

\section{Pajak Hindu}

Pajak Hindu is located on Hindu street No.37, Kesawan. The market operates from 6$11 \mathrm{AM}$. It is the shortest market in Medan, less than 50 meters in length. Travelers out of Medan often makes the market as an object of memorable photos when visiting Medan because there are many cultural heritage sites in the form of historic old buildings nearby.

Pajak Hindu is located on Hindu street. This is a simple naming which is the same as the street name. It aims to help people if they want to shop at the market. They only need to come to Hindu street No. 37. The following sentences are the paraphrases meaning of Pajak Hindu based on the location.

Pajak Hindu (D)

a. D near a place that looks like D

b. Some people think of the same thing as $\mathrm{D}$ before they are at $\mathrm{D}$

c. Some people do not know D

d. If someone says $\mathrm{D}$, some people will think of something good

e. Someone wants to see and get something at D.

Based on the paraphrases above, it can be seen that the Pajak Hindu is a place that near the same place as it which is the Pajak Ikan Lama (a) and because the name of this market is the same as the name of Hindu street, so by saying the name of the market, people will know where it is 
(b). Yet, some people do not know the market (c). It is well-known as a tourist destination in Medan because there are several historic buildings around it. And it is also one of the places to shop for souvenirs in Medan (d, e).

\section{Market Names Based on Time}

\section{Pajak Sore (Afternoon Market)}

Pajak Sore is located in Letjen Jamin Ginting street, Padang Bulan which is near by USU campus. Unlike the Pajak USU, the Pajak Sore various household and kitchen appliances. Pajak Sore is named not because the market operated in the, but it is visited more by buyers in the afternoon. There is a connotative meaning of naming the market. The Paraphrases meaning of the $\mathrm{Pa}$ jak Sore based on time are.
Pajak Sore (E)
a. E looks small
b. E near a place that looks like E
c. Some people do not know E
d. E looks like a short amount of time
e. If someone says E, some people will think of something
f. Someone gets something at D in a short amount of time.

According to the paraphrases above, can be concluded that Pajak Sore is a place that looks small and near to another place, which is the $\mathrm{Pa}$ jak USU $(\mathrm{a}, \mathrm{b})$. Some people do not know it (c). The market is named based on time which is a short afternoon because it is based on the habits of the visitors who come in the afternoon to buy kitchen needs only (d, e). After getting their needs, they will leave immediately. This is the meaning of Pajak Sore by Medanase.

\section{Pajak Pagi (Morning Market)}

Pajak Pagi is located on Sembada street, Padang Bulan Selayang II, Medan Selayang. The market provides people with various daily food needs. The naming of market given by people because this market operates in the morning. Buyers, expecially, mothers visit this place in the morning because they usually cook in the morning. The Paraphrases meaning of the Pajak Pagi are.

Pajak Pagi (F)

a. F looks small b. F near a place bigger than $F$

c. There are some bad things near $F$

d. F looks like a short amount of time

e. If someone says F, some people will think of something

f. Someone gets something at $\mathrm{F}$ in a short amount of time

Based on the paraphrases above, it can be concluded that pajak Pagi is a place that looks small and near a place larger than it, which is Carrefour $(a, b)$. People do not like to come the market because the area is muddy and dirty (c). The market is named based on time which is a short morning because of the customs the Medan people where all activities are carried out in the morning including cooking. So, people come only to buy their cooking needs. Then, they go home to continue their activities $(\mathrm{d}, \mathrm{e}, \mathrm{f})$. This is the meaning of Pajak Pagi by Medanese.

\section{Market Names Based on Environment Condi- tions}

\section{Pajak Ikan Lama (Old Fish Market)}

Pajak Ikan Lama is indeed worthy of being an icon for the Medan people. It is not only because of its good textile collection, but it is also because the place has historical value. According to historians, the market was started in 1890 by a Chinese descent Medan conglomerate, Cong A Fie, at the request of the Dutch Government. The place was originally the center trade for fish, vegetables and various meats. It is no wonder that the name is still attached to the market today. After some time, due to the breakup of fisher-men's transportation relation from Belawan to Medan and the condition of the river that is imposible to sail, the market has finally changed its function. The Market is one of the remnants of Medan's past glory that is still well preserved. The naming of this market is based on the past condition of Medan people and is still maintained today. The paraphrases meaning of Pajak Ikan Lama are.

Pajak Ikan Lama (G)

a. G big

b. $\mathrm{G}$ is near a big place

c. Many people know about $\mathrm{G}$

d. If someone says $\mathrm{G}$, people will think of something that is long ago

e. At $\mathrm{G}$ someone wants to see and get something 
By the paraphrases above, it can be seen that the Pajak Ikan Lama is a large place and near a large place too, which is the Medan Train Station $(a, b)$. Because the market has been around for long time, many people know it. Some people from outside Medan also know it (c). In the beginning, as the name implies, the market was a place to sell fish, but it was in the past. Now it becomes a very famous textile sale center in Medan (d). People usually will look for fabric or just take a look at it (e).

\section{Pajak Ular (Snake Market)}

Pajak Ular is located in Sutomo street, Medan. This market is very familiar market for some people in Medan. This market is famous for buying and selling used goods including the antique and unique ones. Commonly some people buy used goods at the market. The name of the market given by the people was not because it sells snakes, but there are many fraudsters and pickpockets. There is a connotative meaning of naming the Pajak Ular. The paraphares of meaning of the Pajak Ular are.

Pajak Ular (H)

a. H small

b. H near a place that looks like $\mathrm{H}$

c. If someone says $\mathrm{H}$, people will think of something that is not at $\mathrm{H}$

d. There are some bad things near $\mathrm{H}$

e. Some people do not know $\mathrm{H}$

f. Someone at $\mathrm{H}$ wants something.

Based on the paraphrases above, it can be seen that the Pajak Ikan Lama is a small place and near the same place as it seems, which is the $P a$ jak Sambu $(\mathrm{a}, \mathrm{b})$. At the market there are no snakes or people who sell snakes. The word "snake" in the Pajak Ular means someone who has the same character as the snake in connotative meaning which is fraudsters. At this market, there is a lot of fraud and theft (c, d). This market is not as famous as the Pajak Sambu. So, not many people know it. People visit it because they want to buy something (f).

\section{Pajak Bengkok (Crooked Market)}

Pajak Bengkok is located in Aksara street. During rush hour like early morning, there is heavy traffic jam at the market due to street vendors. Besides, the congestion also occurs because pedicabs and urban public transportations that stop randomly at the market. Clothing and food are things sold there.

Pajak Bengkok was due to environmental conditions around the market that has many twists. Medan people see that and call it the Pajak Bengkok. The paraphrases of the meaning of the Pajak Bengkok are:

Pajak Bengkok (I)

a. I big

b. Some people do not know I

c. I is like things that exist

d. There are bad things around I

e. If someone says I, people will think of something

f. Someone at I wants something.

Based on the paraphrases above, it can be seen that the Pajak Bengkok is a large place (a). There are some people who do not know it (b). There are a number of twists that make people call it the Pajak Bengkok. (c) The frequent traffic in the area around this market is an obstacle for people who come to the market (d). This causes them to come only to buy their needs (e).

\section{Pajak Beruang (Bear Market)}

Pajak Beruang is located in HOS Cokroaminoto street, No. 109, Pandau Hulu I Village, Medan Perjuangan District, Medan. The market is a traditional market that famous for its traditional culinary morning. It is owing to from the entrance of the market, people are shown traditional food vendors. It has existed since more or less 1950s. It is named Pajak Beruang because it used to be called Bear street. The price of goods in the market is considered expensive because it sells the good ones. Most people who visit it just want to taste the culinary menu. The naming of the market has begun to lose its meaning, but it is just like the Pajak Ular, bears are also not found at the market. The paraphrases of meaning of Pajak Beruang are:
Pajak Beruang (J)
a. J big
b. $\mathrm{J}$ is a very old place
c. If someone says J, people will think of something that is not at $\mathrm{J}$
d. Some people do not know $\mathrm{J}$
e. Someone at $\mathrm{J}$ wants to feel something. 
Based on the paraphrases above, it can be seen that the Pajak Beruang is a large place and in Bear street, but the street name has changed to HOS Cokroaminoto street No. 109 (a, b). At this market, there are no bears or people selling bears (c). The market is not very well known, so, there are some people who do not know it (d). People come to this place because they want to buy food. This market is famous for its culinary (e).

\section{Pajak Hongkong}

Pajak Hongkong is a place to shop for necessities and to buy Hongkong food. The naming of this traditional market is because the market atmosphere feels like being in Hongkong and the sellers are mostly Chinese descent. The market has been around for hundreds of years. Originally this place was a center for the sale of fabrics or textiles before the fish market was opened hundreds years ago. However, these days the market is selling basic needs like other traditional markets. They sell vegetables, animals (chicken, fish, beef), foods such as pastries and cake, clothing and so forth. The paraphrases of the meaning of this market are:
Pajak Hongkong (K)
a. K big
b. K near a big place
c. K good place
d. Some people do not know K
e. $\mathrm{K}$ like things exist
f. Someone at $\mathrm{K}$ wants something.

Based on the paraphrases above, it can be seen that Pajak Hongkong is a large place near a large place too, namely the Hotel Soechi Novotel $(a, b)$. There are some people who do not know this market (c). This place is clean and well maintained (d). The naming of the market is the idea of people who feel like being in Hongkong. And the sellersare mostly Chinese descent (e). People come to that place because they want to buy food. This market is famous for its culinary (f).

\section{Pajak Sambu}

Pajak Sambu is a traditional market that has existed for a long time in Medan. It is located on Riau Street. The name Sambu refers to the name of a Sambu Island in the Riau Island. This market sells a variety of used clothes from abroad. These imported second-hand clothes are sold cheaply. They are also called "Monza" by the people of North Sumatera. Monza stands for Mongonsidi Plaza, a place in Tanjung Balai City, North Sumatera, which was the pioneer in the sale of imported second hand clothes. Lately Monza has become familiar import used clothes. The paraphrases of the meaning of Pajak Sambu are:

Pajak Sambu (L)

a. L big

b. L b near a place that looks like L

c. Many people know L

d. There are some bad things near L

e. If someone says L, people will think of something far away

f. At L someone wants to see and get something.

Based on the paraphrases above, it I can be seen that the Pajak Sambu is a large place near the place same as it, namely the Pajak Ular $(\mathrm{a}, \mathrm{b})$. This market is very popular because it is open to sell "Monza" (used clothing) every day (c). Pickpocketing often happens frequently here (d). When visiting the market, people should take good care of their staff. When mentioned Pajak Sambu, people who hear it usually think of one island in Riau, namely Sambu Island (e). People who come to that market usually want to see and buy used clothes that are still good with high quality and inexpensive (f).

\section{Discussion}

The discussion of the research is based on the results that have been presented. The results showed that there were three ways in which Medan people gave their market names. They are market names based on location, time, and environmental conditions.

The results of this study are in line with Danesi (2004) saying that names are special nouns. According to her, names become interesting objects of study because of the relationship between the names and the culture of the community where they live. Giving the name of the group or organization is usually denotative which is natural and accepted, but sometimes giving a name to a group or organization can be connotative which has perceptions that are less acceptable and unnatural. Giving a connotative name can occur for two reasons; realized and not realized. Realized means either an organization member or group realize that the dominance of most of the 
characters of the group or organization members lead to one same character even though not all members reflect the group or organization (cf. Algeo, 2010; van Langendonck \& de Velde, 2016).

The name of the market based on the location in Medan is reflected in the naming of Pajak USU which is located around the USU campus, Pajak Petisah located in Medan Petisah district, Pajak Melati located at Melati intersection, Pajak Pringgan located at Pringgan area, pajak Sambas located on Sambas Street, Sukaramai market in Sukaramai II Urban Village, and Pajak Hindu which is on Hindu Street. The seven concepts of market names indicate the denotative meaning because the naming of the market is based on the place or location of the market. Sibarani, et al (2003) explained that denotative meaning (denotation) is the meaning that is in accordance with what it is or meaning that indicates the relationship between words as symbols with their reference as a real world.

The name of the market based on the time can be seen from the naming of the Pajak Sore (Afternoon Market) and Pajak Pagi (Morning market). In naming the Pajak Sore, it does not mean that this market operates only in the afternoon. It is because this market is visitid more by people in the afternoon. This market operates from 08:00 to 18:00. From the concept of the $P a$ jak Sore name, it is drawn the habits of language users who shop in the afternoon to meet their food needs. Unlike the naming of Pajak Sore, the naming of Pajak Pagi is in accordance with the time the market operates, namely in the morning from 05:00-11:00

The names of the market based on environmental conditions can be seen from the naming the Pajak Ikan Lama (Old Fish market), Pajak Ular (Snake market), Pajak Bengkok (Crooked Market), Pajak Beruang (Bear Market), Pajak Hongkong, and Pajak Sambu. In naming the $P a$ jak Ikan Lama, it can be seen the conditions of the market environment. It is known after interviewing informants who stated that the origin of the market name was due to the condition of the market. In the past, this market sold fish and became a center for fish storage, but today the concept of the Pajak Ikan Lama name has a connotative meaning because there are no fish sellers at all in the market. In naming the name of Pajak Ular, it is known from the condition of the environment that there are a lot of fraudsters and pickpockets.
From the name concept of the Pajak Ular, it is thought by Medan people that negative things related to fraud are compared to snakes. The word snake in this case is connotative. In naming the Pajak Bengkok, it can be seen the condition of the environment. According to some Medan people, the naming of this market is because the the market location is crooked. In naming the Pajak Beruang, it can be seen the condition of the market environment in the past. The naming is based on the name of the street which has now been renamed the HOS Cokroaminoto street. In naming the Pajak Hongkong, it can be seen that the people are mostly Chinese offspring and the market atmosphere feels like being in Hongkong. Medan people name the Pajak Hongkong in order to represent the environment of a group. Then, in naming the Pajak Sambu people reflects the conditions of the market environment. Naming this place is different from other market environment conditions. The Sambu name is a description of Riau's island environment which has an island called Sambu Island.

Some market names based on environmental conditions have connotative meaning, such as Pajak Ikan Lama, Pajak Ular, Pajak Hongkong, and Pajak Sambu. According to Sibarani, et al (2003) connotative meaning (connotation) is the meaning that appears because the conceptual/denotative meaning gets additional social attitudes, self-attitudes from one era, personal attitudes, and other additional criteria. This connotative meaning is not permanent, but always depends on the culture of the related nation.

Altman and Low (1992) note that place refers to space that has been given meaning by someone, groups, or cultures. It means through changing space into a place, a geography area has been clung to certain meanings. In short, an attachmentof place is a sense of place.

Toponymic attachment is based on two main concepts, namely toponymic identity and toponymic dependence. Toponymic identity relates to identity of a place, very emotional (psychological) for someone (Williams and Vaske 2003). The identity of the place is also a symbol of the relationship between the physical location and psychic occupants. This construct also consists of four points such as history and memory, community, emotion, and events and activities. These four things affect oneanother in the construct of topinymic identity of a person or group. 
The next construct is toponymic dependence. Toponymic dependence is defined as a person's dependence on the functions of the toponym itself. It is like rubber farmers who depend heavily on their land and rubber resources or an employee on the office as a place of work. Toponymic dependence is divided into three aspects, namely promotion, location, and identification tool. For example, a toponym can function as a tourism promotion way (marketing); toponym can be the location of a place and facilitate the daily communication functions; toponym can be as a useful identification tool on GPS (Geospatial Positioning Service).

The use of the word pajak 'tax' in Medan is not commonly used in Indonesia. For instance, the Land and Building tax which means a compulsory contribution to state revenue, levied by the government on workers' income and business profits but the word pajak 'tax' in Medan is often used to replace the mention of the word market where in general the Indonesian people know the market as a place to sell. Medan people generally mention the word market as a place to sell as the word tax. So far there is no official literature that can explain this fact. If explored, Medan was founded by Karo tribe. So the word tax that refers to the place of selling also comes from the tribe language itself. This is also reinforced by the meaning of the word tax in Karo language which really means a place to sell. Another thing that reinforce the word tax coming from the Karo language is because most of the sellers Medan markets generally are karonese. These sellers are also known as perengge-rengge or traders. Generally, theyare Karonese who live both in Medan and out of Medan (Wong, 2015).

The NSM study has provided a fairly clear picture of the technique which states one form or lexicon for one meaning and one meaning for one form or lexicon (Widani, 2016: 140). The differences between the meaning of each market can be seen from the thought behind the creation of the

\section{REFERENCES}

Algeo, J. (2010). Is a Theory of Names Possible? Names, 58 (2): 90-96.

Altman, I. \& Setha M. L. (1992). In Place Attachment. New York: Plenum Publishing Corporation.

Bach, K. (2002). Giorgione was So-Called Because of His Name, Philosophical Perspectives. Oxford: Oxford University Press. market names. In this study, the paraphrases of the market meaning can provide an understanding of the use of market names used by Medan people.

The novelty of this study compared from the previos studies is the study of the concept meaning of market names in Medan using the theory of natural semantic metalanguage (NSM). The study of the name concept meaning by previous researchers only uses structural semantic theory. Furthermore, some studies also use NSM theory, but in different languages.

\section{CONCLUSIONS}

Based on this study, it can be concluded that there are three ways used by Medan people in giving market names, namely naming market names based on location, time, and environmental conditions. Market names in Medan have denotative or connotative meaning.

The differences between the meaning of each market can be seen from the thought behind the making of the market names. To explain the meaning of market names based on location, the original meaning component of location is used, namely WHERE/PLACE, HERE, NEAR, SIDE, IN. To explain the meaning of the market name based on time, the original meaning component of time is used, namely IF/ TIME, LONG, AWHILE. To explain the meaning of market names based on environment conditions, the original meaning component of space and time, namely WHERE/PLACE, HERE, NEAR, SIDE, IN, IF/ TIME, LONG, the paraphrases of the market meaning can provide an understanding of the use of market names used by Medan people.

Based on the results of the study, it is recommended for further researchers to examine the names of the markets in Medan using cultural theory in order to provide a better understanding of the mindset of Medan people.
Darheni, N. (2010). Leksikon Aktivitas Mata dalam Toponim di Jawa Barat: Kajian Etnosemantik. Jurnal Linguistik Indonesia, 28 (1): 55-67.

Fatikhudin, P. (2018). Penamaan Tempat Usaha Berbahasa Asing di Surabaya: Kajian Semantik Kognitif. BASINDO, 2 (2), 2018: 88-99. http:// journal2.um.ac.id/index.php/basindo 
Gladkova, A. (2002). The Semantics of Nicknames of the American Presidents. Makalah disajikan dalam Conference of the Australian Linguistic Society.

Miles, M.B. \& Huberman, A.M. (1992). Analisis Data Kualitatif. Diterjemahkan oleh Tjetjep Rohendi Rohidi. Jakarta: University Indonesia Pers.

Khotimah, K. \& Ika F. (2019). Kajian Semantik Nama Diri Mahasiswa Madura di Prodi Pendidikan Bahasa dan Sastra Indonesia Universitas Trunojoyo Madura. Jurnal Pendidikan Bahasa dan Sastra Indonesia, 8 (1): 51-55. http://journal. unnes.ac.id/sju/index.php/jpbsi

Moleong, L. J. Metodologi Penelitian Kualitatif Edisi Revisi. Bandung: Remaja Rosdakarya Offset.

Mulyadi \& Rumnasari K. Siregar. (2006). Aplikasi Teori Metabahasa Makna Alami dalam Kajian Makna. Jurnal LOGAT, 11 (2): 69-74.

Munazar, A. (2016). Penamaan 'Lum' pada Kelompok Masyarakat Dinamisme di Bangka Bagian Utara: Sebuah Tinjauan Semantik Pragmatik. Jurnal Society, 6 (2): 27-37.

Palmer. (1981). Semantics: Second Edition. Cambridge: University Press.
Sibarani, R. et. al. (2003). Semantik Bahasa Batak Toba. Jakarta: Pusat Bahasa Depertemen Pendidikan Nasional.

Sudaryanto. (2015). Metode dan Aneka Teknik Analisis Bahasa. Yogyakarta: Sanata Dharma University Press.

Sutopo, H. B. (2002). Metodologi Penelitian Kualitatif: Teori dan Aplikasinya dalam Penelitian. Surakarta: Sebelas Maret University Press.

van Langendonck, W. \& Mark v.d.V. (2016). "Names and Grammar." In The Oxford Handbook of Names and Naming, by Carole Hough, 17-38. Oxford: Oxford University Press.

Widani, N. N. (2016). Makna "Mengambil" Bahasa Bali: Pendekatan Metabahasa Semantik Alami (MSA). Retorika, 2 (1): 127-141. DOI: 10.22 225/jr.2.1.242.124-137

Williams, D. R. \& Jerry J. V. (2003). The Measurement of Place Attachment: Validity. Forest Science, 49 (6): 830-340.

Wong, B. (2015). "Kata Pajak di Kota Medan Berasal dari Bahasa Karo" https://www.kompasiana. com/billwong/5528bbd9f17e61357f8b45bd/ kata-pajak-di-kota-medan-berasal-dari-bahasa -karo 